\title{
Spatial variation in right whale food, Calanus finmarchicus, in the Bay of Fundy
}

\author{
Josée Michaud $^{1,2, *}$, Christopher T. Taggart ${ }^{1}$ \\ ${ }^{1}$ Department of Oceanography, Dalhousie University, 1355 Oxford Street, Halifax, Nova Scotia B3H 4J1 Canada \\ ${ }^{2}$ Present address: Pavillon Alexandre-Vachon, Room 4081, 1045, avenue de la Médecine, Université Laval, Québec, \\ Québec G1V 0A6, Canada
}

\begin{abstract}
We quantified small- and basin-scale variation in the energy available in right whale (Eubalaena glacialis) food, Calanus finmarchicus Copepodite-5 (C5), as a function of depth, tidal variation and circulation during the late-summer feeding period in the Grand Manan Basin of the Bay of Fundy. Food energy density $\left(\mathrm{kJ} \mathrm{m}^{-3}\right)$ is a function of $\mathrm{C} 5$ concentration $\left(\mathrm{m}^{-3}\right)$ and individual C5 lipid energy content $(\mathrm{J})$ that increases by 2 orders of magnitude from near the surface to $\sim 18 \mathrm{~kJ}$ $\mathrm{m}^{-3}$ at $\sim 160 \mathrm{~m}$ depth; this observation helps explain why right whales concentrate their foraging efforts at depth. Food energy density can vary by a factor of 4 over a tidal cycle and 3.5 over a horizontal distance of $\sim 2 \mathrm{~km}$ in the deeper strata of the Basin. By tracing water mass trajectories, we show that it is the warmer, saltier and denser water that contains the highest food energy density that is tidally advected within the Basin. At the scale of the Basin (10s of kilometres) we observed maximum food energy densities of $\sim 25 \mathrm{~kJ} \mathrm{~m}^{-3}$ in the 140 to $160 \mathrm{~m}$ depth stratum where the highest energy densities spatially coincide with the highest historical right whale concentrations. We concluded that the tidal variation and tidally driven circulation represents the simplest explanation for the distribution of food energy density and for the distribution of right whales in the Grand Manan Basin region and that Basin topography and water mass excursions associated with tidal currents facilitate the persistence of C5 aggregations in the dense deep water.
\end{abstract}

KEY WORDS: Right whale $\cdot$ Calanus finmarchicus $\cdot$ Energy content $\cdot$ Tide $\cdot$ Bay of Fundy

\section{INTRODUCTION}

The North Atlantic right whale Eubalaena glacialis is an Endangered species, and population dynamics modeling, based on demographics from the 1990s, predicted extinction likelihood within the next 200 years (Caswell et al. 1999, Fujiwara \& Caswell 2001). Explanations for limited population growth and recovery include fishing gear entanglements and ship strikes (Kraus et al. 2005) that are responsible for approximately half of the reported deaths (Moore et al. 2007) and low reproductive rates (Knowlton et al.
1994, Kraus et al. 2001). It has been postulated that declines in the reproductive rate and variation in the summer distribution of the whales over the past 2 decades (Clapham \& Cole 1999, Brown et al. 2001, Kraus et al. 2001) may be explained by variation in food quality and/or availability (Payne et al. 1990, Kenney et al. 1995, 2001, Fujiwara \& Caswell 2001, Patrician \& Kenney 2010). Approximately one-third of the known right whale population migrates annually to primary feeding habitat in the Grand Manan Basin, lower Bay of Fundy in eastern Canada (Schaeff et al. 1993). The energy available in the prey field 
in the Basin will influence whale foraging success, health, survival and reproductive capacity (Lockyer 1984, Reeves 2001). The essential data for quantifying food abundance and quality in the Grand Manan Basin are indirect and insufficient to adequately address this postulate, e.g. secondarily inferred (Patrician \& Kenney 2010), though there is an acknowledged need to obtain insights on right whale feeding habitat characteristics and productivity to better orient conservation efforts (Baumgartner \& Mate 2003, DeLorenzo Costa et al. 2006).

The diving behaviour of right whales in the Grand Manan Basin is characteristic of foraging at depths of 75 to $175 \mathrm{~m}$ (Baumgartner \& Mate 2003), where the diapausing Calanus finmarchicus Copepodite Stage 5 (C5) dominates the summer and autumn mesozooplankton community (Murison \& Gaskin 1989, Baumgartner et al. 2003a, Michaud \& Taggart 2007). Such studies in the Bay of Fundy and on the adjacent Scotian Shelf (McLaren and Corkett 1984, McLaren et al. 2001) indicate that the zooplankton summer-autumn assemblage can be composed of several generations of C5 individuals, and thus of different physiological state and energy content.

At seasonal scales, estimates of Calanus finmarchicus C5 abundance, lipid content and gross energy content integrated over the water column are highest in the Basin during August and September when the whales are most abundant, and the monthly (May through October) increase in energy density $\left(\mathrm{kJ} \mathrm{m}^{-3}\right)$ provided by the C5s is strongly and positively correlated $\left(r^{2}=0.88, p=0.0178\right)$ with the monthly increase in right whale abundance (Michaud \& Taggart 2007). Feeding success depends not only on temporal matching of the predator and prey, but also on spatial matching where food energy density may be influenced by local oceanographic forcing over the foraging time and space scales of right whales in the Basin. The semidiurnal tidal currents in the Grand Manan Basin can exceed $1 \mathrm{~m} \mathrm{~s}^{-1}$, the tidal amplitude can reach $5 \mathrm{~m}$ and the tidal excursion along the major axis (SW to NE) of the tidal ellipse is $\sim 8 \mathrm{~km}$ (Greenberg 1983). Given that the Bay of Fundy is one of the most tidally energetic regions in the world, tidal variation and associated circulation probably influence the C5 prey field. Baumgartner et al. (2003a) suggest that the strong correlation between right whale sighting rates and local concentrations of $\mathrm{C} 5 \mathrm{~s}$ in the Basin is associated with tidal variation and probably stems from the coincident advection of the whales and their food. Historical right whale sightings per unit effort data show that the probability density distribution of the whales is centred over the Grand
Manan Basin (Vanderlaan et al. 2008). This distribution probably coincides with the basin-scale spatial distribution of their food, although this relationship and the influence that oceanographic processes in the area may have on the distribution remain to be quantified.

The above observations and postulates led us to first determine whether C5 energy density is most concentrated at depth in the Grand Manan Basin during the right whale primary feeding period, and in what quantities. Second, we determined whether the spatial (metre to kilometre scales) and temporal (hour to day scales) variation in the energy density at depth is a function of water mass characteristics and tidal forcing in the Basin, as suggested by Baumgartner et al. (2003a). Finally, we examined basin-scale (10s of kilometres) spatial patterns in energy density in relation to the abundance distribution of the right whales.

\section{MATERIALS AND METHODS}

\section{Sampling}

Zooplankton samples were collected at several stations in the Grand Manan Basin aboard the CFAV 'Quest' on 13 and 14 September 2002 (Fig. 1, Table 1) with a BIONESS (Bedford Institute of Oceanography Net and Environment Sensing System; Sameoto et al. 1980) towed at a nominal $1 \mathrm{~m} \mathrm{~s}^{-1}$ and equipped with six $333 \mu \mathrm{m}$ mesh nets $\left(1 \mathrm{~m}^{2}\right.$ aperture, $1.5 \mathrm{~m}$ length) that allowed for depth-stratified sampling. The BIONESS was fitted with an SBE-19 CTD (Sea-Bird Electronics), 2 G.O. flowmeters (General Oceanics) to estimate filtered volume and an optical particle counter (OPC-1T; Herman 1988, 1992). Four sampling stations were located in the same geographic vicinity to obtain a tidal-cycle time series (Stns 1 to 4). Sampling extended from 21:43 h UTC (18:43 h Atlantic Daylight Saving Time, ADST) on 13 September to 10:02 h UTC (07:02 h ADST) on 14 September. At each station, Net 1 collected material from the surface to $\sim 10 \mathrm{~m}$ above the bottom, while Nets 2 through 6 were sequentially opened and closed to sample discrete depth strata (Table 1) in a stepwise manner from near bottom to near surface. At Stn 5, Nets 2 through 6 were sequentially opened and closed at the same depth $(\sim 107 \mathrm{~m})$ while under tow to provide a space series within the deep scattering layer that was indicated on the vessel's echo sounder (Simrad ${ }^{\circledR}$ EK500). Depth-integrated collections from Net 1 are not used here and are presented in Michaud \& Taggart (2007). Net collection results are reported accord- 


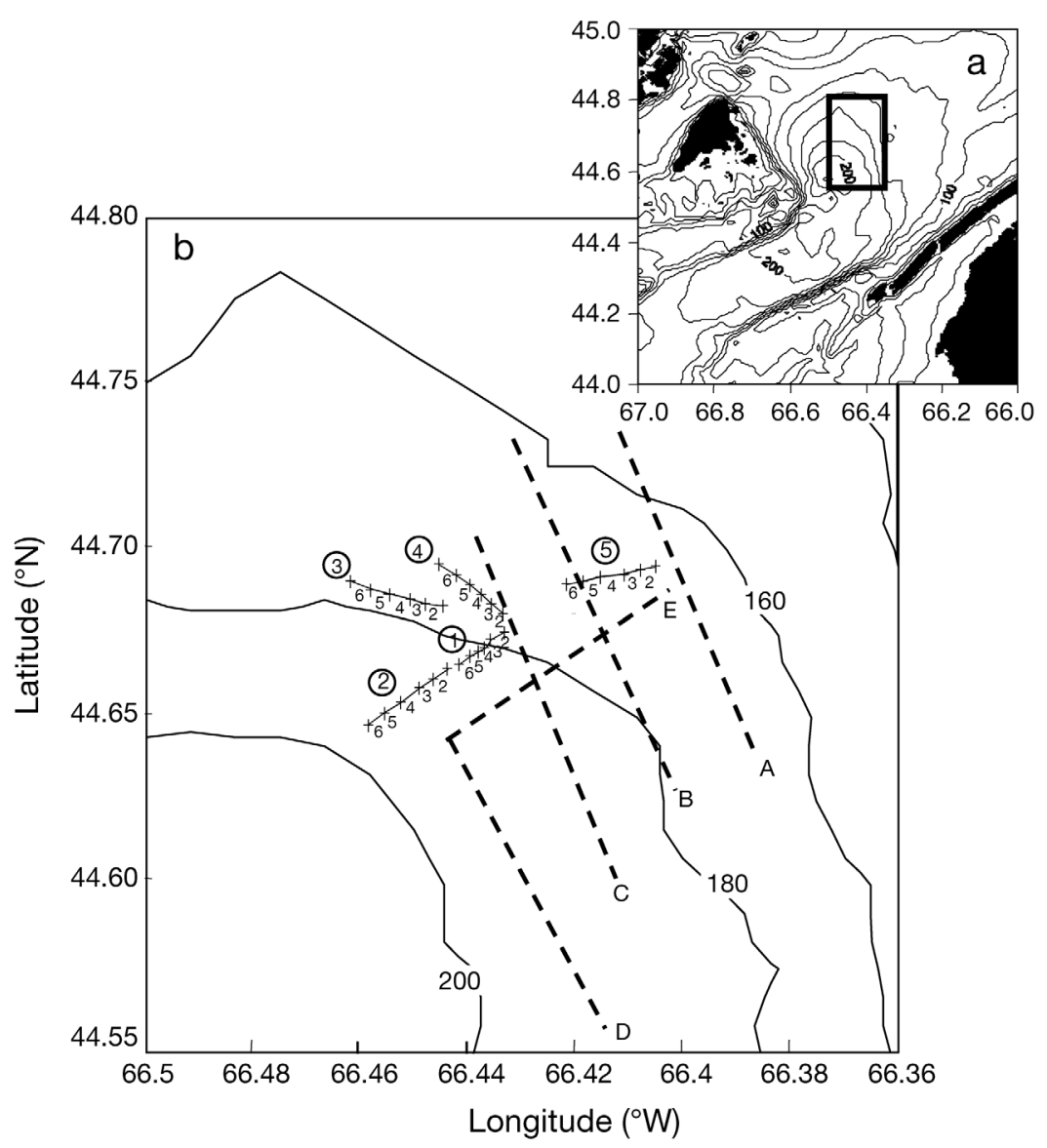

Fig. 1. Bathymetric (20 m resolution) charts of (a) Grand Manan Basin region, Bay of Fundy, showing the sampling area (inset rectangle), and (b) geographic locations of stations (Stns 1 to 5) and transects (A to E) occupied in September 2002. Station number is circled, lines indicate the depth-specific, net-sampling geographic trajectory, crosses indicate the location of opening and closing of the sequential nets, and the numbers below the trajectories indicate the net number (Nets 2 to 6 ) ployed immediately before the Stn 5 BIONESS tow were used to cross-calibrate the inferior SBE-19 CTD aboard the BIONESS.

A second OPC, fitted on an Endeco ${ }^{\circledR}$ V-fin, along with a G.O. digital flowmeter and an OS $^{\circledR}-2000$ CTD were also used. This towed underwater biological sensor system (TUBSS; Taggart et al. 1996, Sprules et al. 1998) was deployed in an undulating manner from near surface to a maximum depth of $180 \mathrm{~m}$ with nominal vertical and horizontal speeds of $1 \mathrm{~m} \mathrm{~s}^{-1}$ along a series of 5 transects (Fig. 1b) over the period 11 through 18 September 2002. Transects were repeatedly transited over a tidal period (Table 2). The TUBSS data (GPS navigation, plankton number at size, depth, pitch, tow speed) were provided in real time and logged. The volume sampled was estimated as the product of tow speed through the water, elapsed time and the cross-sectional area of the OPC sampling tunnel; the latter was corrected for variation in pitch. No data were available for $58 \mathrm{~min}$ on Transit 3 of Transect B and for 36 min on Transit 1 of Transect $\mathrm{C}$ due to serial-interface interruptions. All data from all sensors were quality controlled. Time is reported as UTC (ADST - $3 \mathrm{~h})$.

\section{Sample analyses}

tum. A $5 \mathrm{ml}$ subsample of zooplankton from each net collection was frozen immediately in liquid nitrogen and the remainder preserved in $4 \%$ buffered formalin. An SBE-25 profiling CTD (Sea-Bird Electronics) was deployed immediately before each BIONESS tow. The down-cast data provided by the SBE-25 CTD de-
Formalin-preserved plankton and fresh-frozen subsamples were weighed $( \pm 0.001 \mathrm{~g})$ to estimate wet biomass for each net collection. For each collection, zooplankton concentration $\left(\mathrm{m}^{-3}\right)$ was estimated, and

Table 1. Zooplankton net-sampling characteristics among stations occupied in the Grand Manan Basin, Bay of Fundy, in September 2002 detailing the mid-tow location (decimal latitude and longitude) and time (UTC) and the depth stratum sampled by each net from the deepest (Net 2) to the shallowest (Net 6)

\begin{tabular}{|lccccccccc|}
\hline $\begin{array}{l}\text { Stn } \\
\text { no. }\end{array}$ & Date & $\begin{array}{c}\text { Mid-tow time } \\
\text { (h:min) }\end{array}$ & $\begin{array}{c}\text { Latitude } \\
\left({ }^{\circ} \mathrm{N}\right)\end{array}$ & $\begin{array}{c}\text { Longitude } \\
\left({ }^{\circ} \mathrm{W}\right)\end{array}$ & Net 2 & \multicolumn{2}{c|}{ Nange (m) in depth stratum sampled } \\
\hline 1 & 13 Sep & $21: 43$ & 44.6701 & 63.4342 & $175-153$ & $154-98$ & $99-50$ & $51-22$ & $23-0$ \\
2 & 14 Sep & $01: 46$ & 44.6667 & 66.4385 & $180-152$ & $150-100$ & $100-50$ & $50-20$ & $20-0$ \\
3 & 14 Sep & $05: 40$ & 44.6848 & 66.4500 & $169-153$ & $153-120$ & $120-48$ & $47-32$ & $32-0$ \\
4 & 14 Sep & $10: 02$ & 44.6861 & 66.4370 & $174-149$ & $149-128$ & $128-70$ & $70-33$ & $32-0$ \\
5 & 14 Sep & $19: 45$ & 44.6915 & 66.4099 & $113-110$ & $110-109$ & $109-107$ & $112-107$ & $112-106$ \\
\hline
\end{tabular}


Table 2. Characteristics of each transit among 4 transects sampled with the towed underwater biological sensor system (TUBSS) in the Grand Manan Basin during 11 to 18 September 2002, providing dates, time (UTC) and positions, along with nominal headings and sampling depths. Transects were 12 to $14 \mathrm{~km}$ long and each was consecutively transited between 2 (Transects D and E) and 4 times (Transects A, B and C) over a tidal period

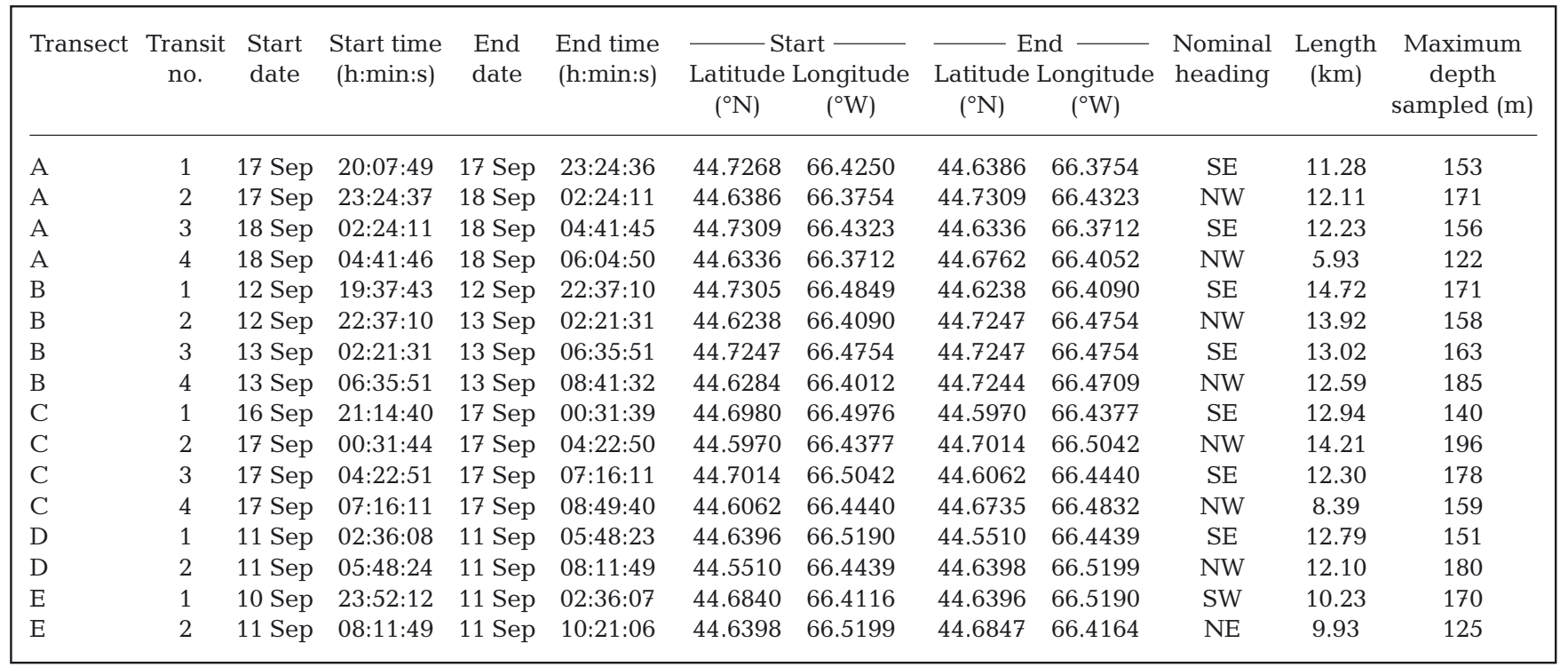

between 10 and 50 individual C5s from the frozen material were measured and analysed for lipid content (detailed in Michaud \& Taggart 2007).

Food energy density in the water $\left(\mathrm{kJ} \mathrm{m}^{-3}\right)$ was estimated as the product of the station- and depthspecific $\mathrm{C} 5$ concentration $\left(\mathrm{m}^{-3}\right)$ and the station- and depth-specific C5 average-individual wax ester (WE) content $(\mu \mathrm{g})$ that was converted to energy by means of a conversion factor of $39.5 \mathrm{~kJ} \mathrm{~g}^{-1} \mathrm{WE}$ (Lamprecht 1999). We focused on WE because it represents $\sim 70 \%$ of the lipid classes in the C5s in the August to September period (Michaud \& Taggart 2007) and it is the class that contains the most energy (Kattner \& Hagen 1995). Energy density variance was estimated as the sum of $\mathrm{C} 5$ concentration variance and WE content variance. Covariance was ignored by reasonably assuming that fluctuations in C5 concentration and WE content are independent (Bevington \& Robinson 2003). Collection estimates from each station were aggregated among the deep-water $(>125 \mathrm{~m}$; Nets 2 and 3), mid-water (30 to $125 \mathrm{~m}_{i}$ Nets 4 and 5) and surface-water $\left(<30 \mathrm{~m}_{i}\right.$ Net 6$)$ strata to evaluate the temporal variation in C5 size and lipid content at depth.

\section{Tidal advection}

Tidal elevation and current estimates for the sampling series stations (Stns 1 through 4) were determined by using a tidal prediction model (WebTide $\mathrm{v}$.
0.65, Ocean Science Division, Bedford Institute of Oceanography). Model predictions are based on barotropic assumptions (Hannah et al. 2001). Model estimates relied on the grand mean position of the 4 stations for the start, 1 min time steps and the M2, K1, $\mathrm{N} 2, \mathrm{~S} 2$ and $\mathrm{O} 1$ tidal constituents along with residual circulation.

We used a drift prediction model (WebDrogue v. 0.66, Ocean Science Division, Bedford Institute of Oceanography; see also Lynch et al. 1992, Hannah et al. 2001) to define the Lagrangian path of the sampled water masses. The model was used to hindcast the geographic origin and forecast the destination of each of the 4 water masses sampled at depth with the BIONESS over the $\sim 12.5 \mathrm{~h}$ tidal cycle (Table 3). Water-mass trajectories were based on the $100 \mathrm{~m}$ stratum (model maximum) and the tidal constituents and residual listed above. Forecast trajectories determined the approximate geographic destination of each water mass at the time that the sampling series ended $12.5 \mathrm{~h}$ later $(09: 57 \mathrm{~h}$ on 14 September 2002, the mid-tow sampling time at Stn 4, Table 1). Hindcast trajectories determined the approximate geographic origin of each water mass at the time that the sampling series began (21:33 h on 13 September 2002, the mid-tow sampling time at Stn 1, Table 1). These trajectories allowed us to determine when and where the same water mass was sampled as it was being advected within the Basin during 1 tidal cycle, as well as the tidal excursion of the water mass. 
Table 3. Initial position (latitude and longitude) and start and end sampling date and time (UTC) for the deep net (Net 2) of each station series (Stns 1 to 4) collection in the Grand Manan Basin in 2002

\begin{tabular}{|c|c|c|c|c|c|}
\hline \multirow{2}{*}{$\begin{array}{l}\text { Stn } \\
\text { no. }\end{array}$} & \multirow{2}{*}{ Date } & \multirow{2}{*}{$\begin{array}{l}\text { Latitude } \\
\left({ }^{\circ} \mathrm{N}\right)\end{array}$} & \multirow{2}{*}{$\begin{array}{l}\text { Longitude } \\
\qquad\left({ }^{\circ} \mathrm{W}\right)\end{array}$} & \multicolumn{2}{|c|}{ Time (h:min) } \\
\hline & & & & Start & End \\
\hline 1 & $13 \mathrm{Sep}$ & 44.6761 & 66.4284 & $21: 33$ & $21: 38$ \\
\hline 2 & $14 \mathrm{Sep}$ & 44.6667 & 66.4385 & $01: 36$ & 01:41 \\
\hline 3 & $14 \mathrm{Sep}$ & 44.6804 & 66.4394 & $05: 30$ & $05: 35$ \\
\hline 4 & 14 Sep & 44.6775 & 66.4304 & 09:51 & $09: 57$ \\
\hline
\end{tabular}

\section{OPC data analyses}

Plankton particles measured and counted by the OPCs aboard the BIONESS and TUBSS were analyzed to determine $\mathrm{C} 5$ concentration and relied on a linear regression calibration $\left(\mathrm{r}^{2}=0.84, \mathrm{p}<0.0001, F-\right.$ ratio $=170, \mathrm{n}=34$ ) of OPC data by using C5 size and concentration estimates provided by the simultaneous BIONESS net collections. Data treatment and calibration details are provided in the supplementary material available at www.int-res.com/articles/suppl/ n015p179_supp.pdf.

The sectional series of the TUBSS OPC-derived C5 concentration estimates were smoothed twice by using centered, uniformly weighted, moving averages with windows of extent $5(2.5 \mathrm{~s})$ for the first pass and extent 7 (3.5 s) for the second. Sections were contoured (Surfer ${ }^{\circledR}$ v.8, Golden Software) using an inverse distance-squared algorithm, search ellipse radii of $\sim 10 \mathrm{~m}$ vertical and $\sim 1$ to $1.5 \mathrm{~km}$ horizontal, 4 -sector search, datum maxima of 16 per sector and no more than 3 null grid sectors. Grid nodes were blanked where there were fewer than 8 data points. Basin-scale energy density sections of the C5 prey field were estimated as the product of the $\mathrm{C} 5$ concentration at each grid node and the average individual WE content $(113.6 \mu \mathrm{g}, \mathrm{SD}=$ $56.12 \mu \mathrm{g}$ ) of C5s collected with the BIONESS in the deep-water stratum and expressed as $\mathrm{kJ} \mathrm{m}^{-3}$.

To obtain a planar distributional estimate of energy density $\left(\mathrm{kJ} \mathrm{m}^{-2}\right)$ at depth from the sectional transit data, estimates of energy density $\left(\mathrm{kJ} \mathrm{m}^{-3}\right)$ at each grid node were first summed over the depth of each of 3 strata (100 to 120,120 to 140 and 140 to $160 \mathrm{~m}$ ) and divided by the depth of the stratum $(20 \mathrm{~m})$. Where data were missing for a specific stratum (rare), the most conservative estimate was provided by using the estimate from the overlaying stratum. Using the WebDrogue model as described above, the average food energy density estimates for each grid node were then 'advected' from their various sampling times and geographic locations to common times at either end of the tidal excursion (at high and low tide) to obtain quasi-synoptic planar estimates in water-mass space. Advection of the energy density in this manner assumes isotropy (Taylor's frozen field) over the 14 tidal cycles of the $7 \mathrm{~d}$ period needed to complete the TUBSS transects. Once advected, the estimates were grid-contoured as above using an isotropy angle of $30^{\circ}$ approximating the main axis of the tidal ellipse (SW to NE) in the Basin.

Statistical analyses were performed on normal or normalized data and ANOVA p-values are presented except where otherwise stated. A posteriori comparisons of normal or normalized data relied on the Tukey-Kramer Honestly Significant Difference (HSD) test with $\alpha=0.05$. Significant digits are presented in accord with convention. All cartographic illustrations are equidistance cylindrical projection.

\section{RESULTS}

\section{Hydrography of the station series}

The stations at the beginning (Stn 1) and at the end (Stn 4) of the BIONESS sampling series (Fig. 1) were sampled near high tide while the intervening stations (Stns 2 and 3) were sampled on either side of low tide (Fig. 2a). As the average of the pairwise distances of the initial geographic locations of these 4 stations

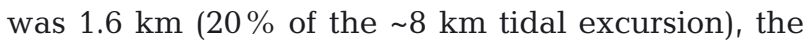
temporal variation among these stations was greater than their geographic variation over time. Thus, we can reasonably assume that these stations represent the same geographic space through which the water masses were tidally advected. Stn 1 was sampled in the evening near high tide, Stns 2 and 3 at night on the ebb- and flood-side of low tide, respectively, and Stn 4 in early morning, near high tide (Fig. 2a). Tidal currents were relatively weak at the beginning of the series and strengthened to $0.5 \mathrm{~m} \mathrm{~s}^{-1}$ at the time that Stns 2 (ebbing) and 3 (flooding) were occupied (Fig. 2b). At the end of the series the current had weakened to $<0.1 \mathrm{~m} \mathrm{~s}^{-1}$.

Tidal advection is the simplest explanation for observed variations in water column characteristics. The temperature-salinity (TS) signatures over the 0 to $40 \mathrm{~m}$ depth were similar at all tidal stages (Fig. 3) and reflected the well-mixed surface layer. At depths $\geq 80 \mathrm{~m}$, the signatures among profiles reflected distinct tidally related variation characterised by a transition from a warm and salty TS signature near high tide (Stn 1) to a colder and fresher signature near low tide (Stns 2 and 3) and then a return to the warm and 

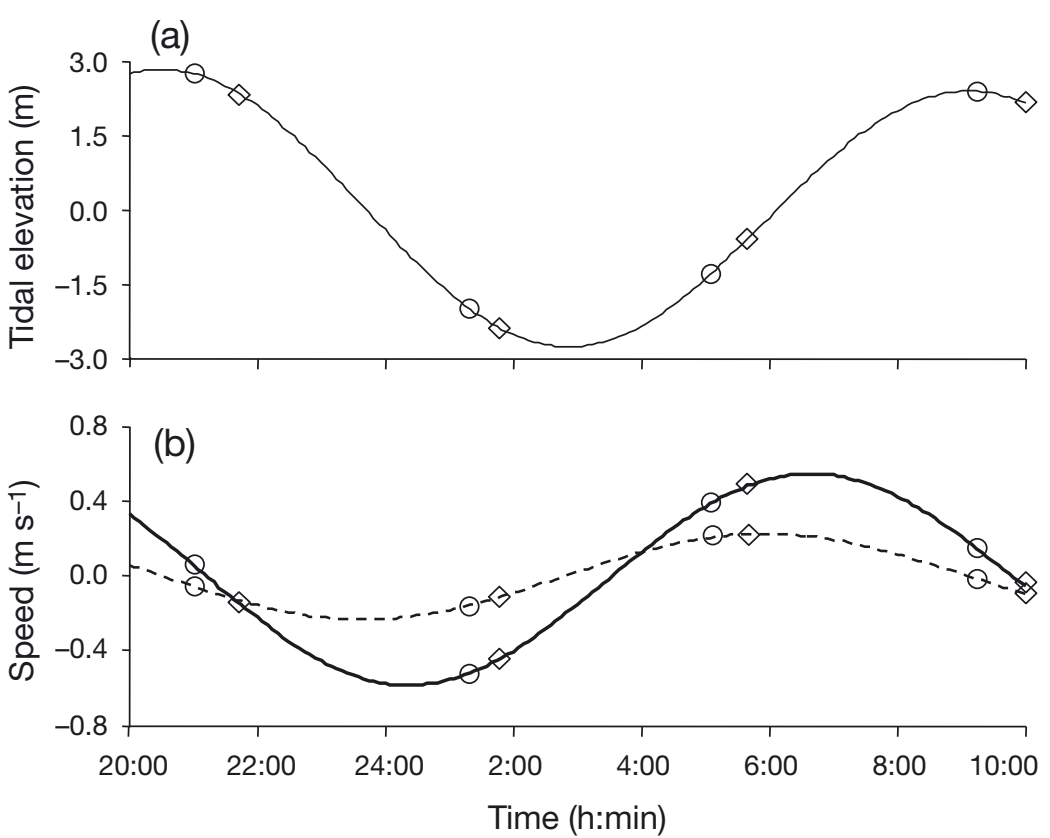

Fig. 2. Semidiurnal variation in (a) tidal elevation and (b) E-W (dashed line: $+\mathrm{E}$ [current vector, eastward]) and $\mathrm{N}-\mathrm{S}$ (solid line: $+\mathrm{N}$ [current vector, northward]) current speed over the period from 20:00 h, 13 September to 10:00 h, 14 September 2002 (UTC) at sequential sampling Stns 1 to 4 in the Grand Manan Basin. $\diamond$ : mid-time for each sequential BIONESS net-tow series; O: mid-time of each sequential CTD (SB-25) profile

salty signature again near high tide (Stn 4). There was also evidence of density compensation among profiles in the 80 to $120 \mathrm{~m}$ depth stratum; i.e. depthspecific densities $\left(\sigma_{t}\right)$ were similar, but the water at

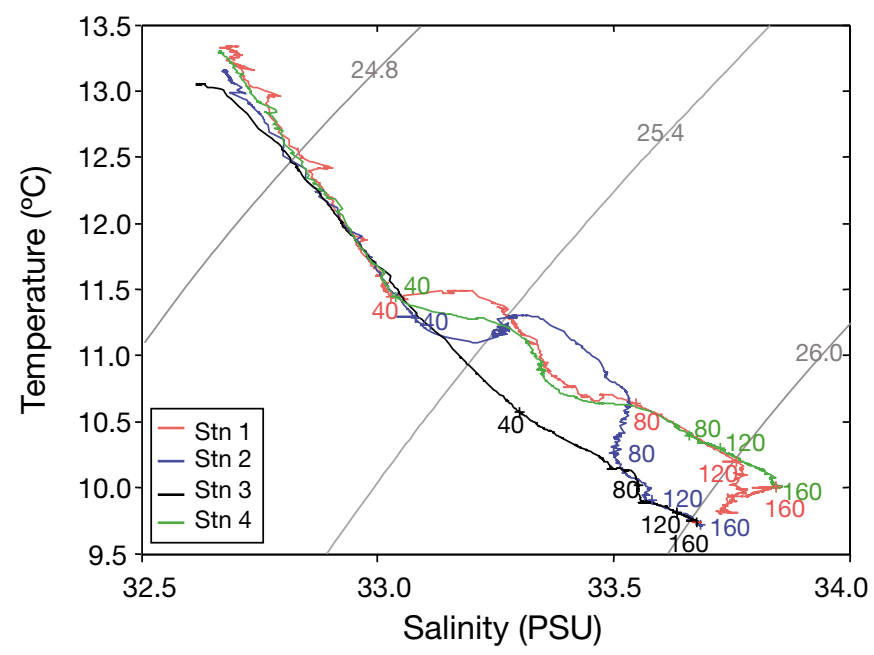

Fig. 3. Semidiurnal tidal variation in temperature-salinity (TS) diagrams derived from CTD profiles in the Grand Manan Basin and associated with each of the 4 BIONESS sampling series stations - 1 (red), 2 (blue), 3 (black) and 4 (green)-over the period from 20:00 h, 13 September through 10:00 h, 14 September 2002 (UTC). Each $40 \mathrm{~m}$ depth increment in each profile is noted, as are the lines of constant density $\left(\sigma_{t}\right)$ high tide was warmer and saltier than that at low tide. However, and notably, (1) water near the bottom at $160 \mathrm{~m}$, at the time of Stns 1 and 4 near high tide, was more dense than the water at the same depth at the time of Stns 2 and 3 near low tide, and (2) as depth increased from 120 to $160 \mathrm{~m}$ at Stn 1, the TS signature diverged from that associated with the time of Stn 4 (also near high tide) toward the signature associated with Stns 2 and 3 and then returned toward the TS signature and density associated with Stn 4 at $160 \mathrm{~m}$ depth.

The forecast and hindcast trajectories from the tidal advection model of the deep water associated with the 4 stations (i.e. Net 2 sampling) indicated that the waters sampled at Stns 1 and 4 were closer to each other in water-mass space than they were to those sampled near low tide at Stns 2 and 3 and vice versa (Fig. 4), which was consistent with the TS signatures described above. The forecast trajectory of the high-density deep water associated with Stn 1 (Fig. 4a) showed it was advected down-slope in a SW direction, crossing the 180-200 m isobaths. The deep water associated with Stns 2 and 3 (initially $2 \mathrm{~km}$ apart) had similar forecast trajectories though advected in an up-slope NE direction, crossing the 180-160 m isobaths. The end points of these 2 water masses were separated by $1.9 \mathrm{~km}$ and were located 8.4 and $8.1 \mathrm{~km}$ from their initial positions, consistent with the expected tidal excursion in the Basin. According to the hindcast trajectories (Fig. 4b), the origins of the Stns 2 and 3 deep water masses were to the NE near the $140 \mathrm{~m}$ isobath, while the deep water mass associated with Stn 4 originated close $(1.8 \mathrm{~km})$ to that associated with Stn 1 and was advected downslope over a depth range of 180 to $200 \mathrm{~m}$ and then upslope when the tide turned.

\section{Zooplankton biomass, C5 concentration and energy content at tidal scales}

Variation in water-mass properties over the tidal cycle described above is reflected in the vertical distribution of zooplankton. The vertical distributions of zooplankton wet biomass were similar for the Stns 1 and 4 collections secured near high tide and for the 


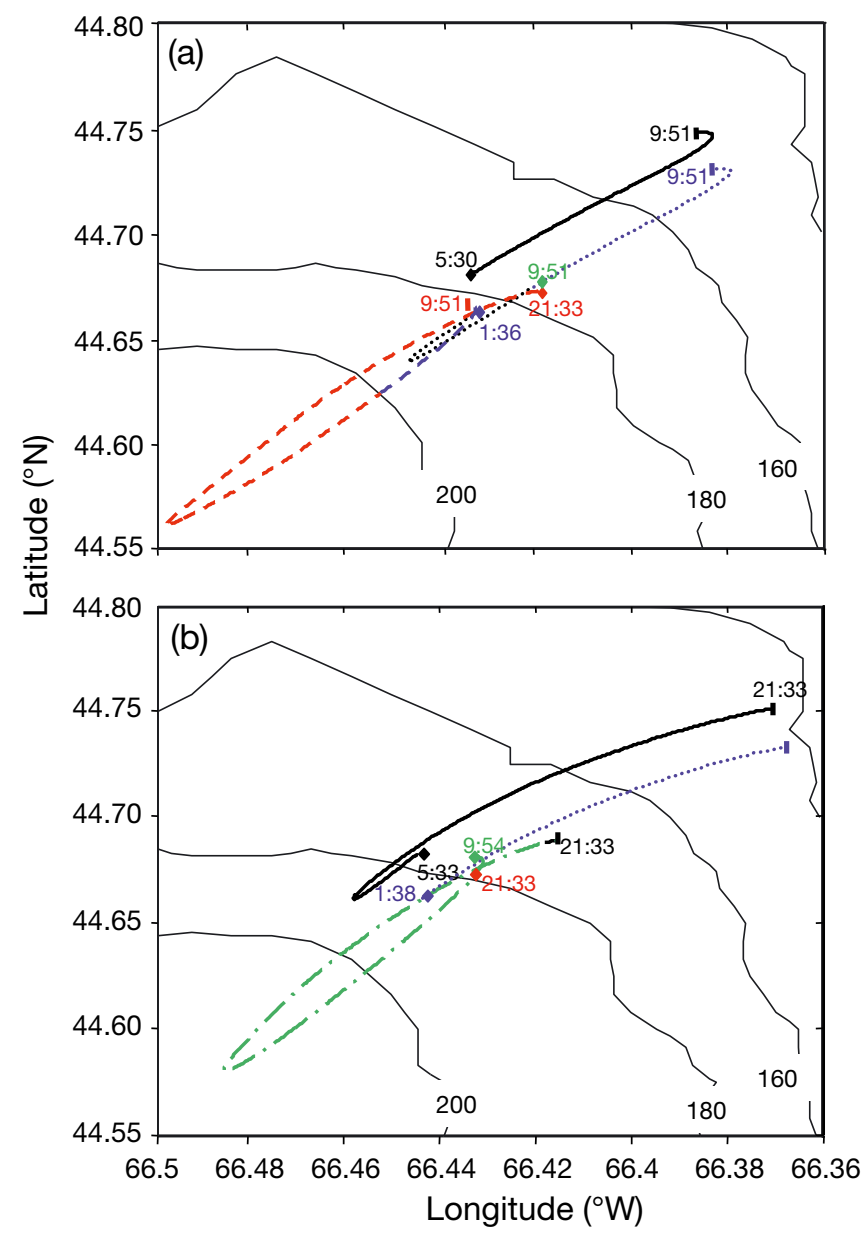

Fig. 4. Estimated $100 \mathrm{~m}$ depth water-mass trajectories associated with each BIONESS deep-water station-series collection (Net 2) for (a) forecast to the common time of 09:51 h, 14 September 2002 UTC and thus location (short vertical bars), and (b) hindcast to the common time of 21:33 h, 13 September 2002 UTC and thus location (short vertical bars). Both trajectories are presented according to the time and location that Net 2 was opened (diamonds). Stn 1 (red dashed line), Stn 2 (dotted blue line), Stn 3 (solid black line) and Stn 4 (green dashed-and-dotted line) were sampled sequentially between 20:00 h, 13 September and 10:00 h, 14 September 2002 UTC

Stns 2 and 3 collections at night and near low tide (Fig. 5a). Zooplankton wet-biomass estimates in the near-surface stratum (less than $\sim 40 \mathrm{~m}$ ) at all stations and tidal stages were similar $\left(<1 \mathrm{~g} \mathrm{~m}^{-3}\right)$, consistent with the unchanging surface layer TS signature described in Fig. 3 above. In the deep-water stratum $(>125 \mathrm{~m})$ the biomass estimates in the warmer and saltier water mass associated with Stns 1 and 4 were 2 - to 4 -fold greater than in the colder and fresher water mass associated with Stns 2 and 3. Most of the variation in the total zooplankton wet biomass was attributable to Calanus finmarchicus, which numeri- cally represented between 83 and $93 \%$ of the zooplankton in the surface stratum and between 96 and $99 \%$ of the zooplankton in the deeper strata. Concentration estimates of $C$. finmarchicus C5 throughout the water column were an order of magnitude greater than the other stages that were mostly adults and C4s (see Michaud 2005, Michaud \& Taggart 2007). The C5 concentrations increased with depth and were generally 3 -fold greater in the warmer and saltier water associated with the deep water at Stns 1 and 4 than in the colder and fresher water associated with Stns 2 and 3 (Fig. 5b).

Individual WE content among C5s showed appreciable vertical and depth-specific temporal variation (Fig. 5c). Average WE content increased with depth in water associated with Stns 1 and 4 (Fig. 5c) as did C5 concentration (Fig. 5b). Though higher at depth in water associated with the time of Stns 2 and 3, the vertical distribution was more variable and tended toward bimodal (Fig. 5c). Average WE content in Stn 1 water reached $132 \mu \mathrm{g}$ at $165 \mathrm{~m}$ and was no different than at $130 \mathrm{~m}$, and both estimates were higher than in any overlying stratum (HSD test: $p<0.0001$ ). Average WE in Stn 2 water covered the same range as in Stn 1 water, and the maxima at 75 and $165 \mathrm{~m}$ were higher than at 10 and 135 m (HSD test: p < 0.0001). The individual WE estimates in Stn 3 water reached $113 \mu \mathrm{g}$ in the surface stratum where it was no different than at $160 \mathrm{~m}$, and both were higher than that in the intervening strata (HSD test: $\mathrm{p}<0.0001$ ). Average individual WE content in Stn 4 water was similar over depth in a manner similar to Stn 1 water, and the maximum $(145 \mu \mathrm{g})$ at $140 \mathrm{~m}$ was higher than that in all other strata (HSD test: $\mathrm{p}<0.0001$ ).

Food energy density $\left(\mathrm{kJ} \mathrm{m}^{-3}\right)$ in the water column increased by 2 orders of magnitude with depth and varied more than 4 -fold at depth with time and, thus, with the water mass trajectories associated with tidal advection (Fig. 5d). Food energy density estimates were similarly highest in water associated with Stns 1 and 4 (near high tide) and increased from $<0.2 \mathrm{~kJ} \mathrm{~m}^{-3}$ near the surface to $>10 \mathrm{~kJ} \mathrm{~m}^{-3}$ at depths $\geq 125 \mathrm{~m}$. The vertical distributions of C5 energy density in water associated with Stns 2 and 3 (near low tide) were similar, increased marginally with depth and did not exceed $6.7 \mathrm{~kJ} \mathrm{~m}^{-3}$. Energy density in the surface stratum never exceeded $0.6 \mathrm{~kJ} \mathrm{~m}^{-3}$. Perhaps most importantly, energy density in the deep-water stratum demonstrated a 4 fold systematic change over the tidal period with maximum energy density in the deeper warm and salty water associated with Stn $1\left(15 \mathrm{~kJ} \mathrm{~m}^{-3}\right)$ and Stn $4\left(18 \mathrm{~kJ} \mathrm{~m}^{-3}\right)$. 
(a) Zooplankton biomass $\left(\mathrm{g} \mathrm{m}^{-3}\right)$

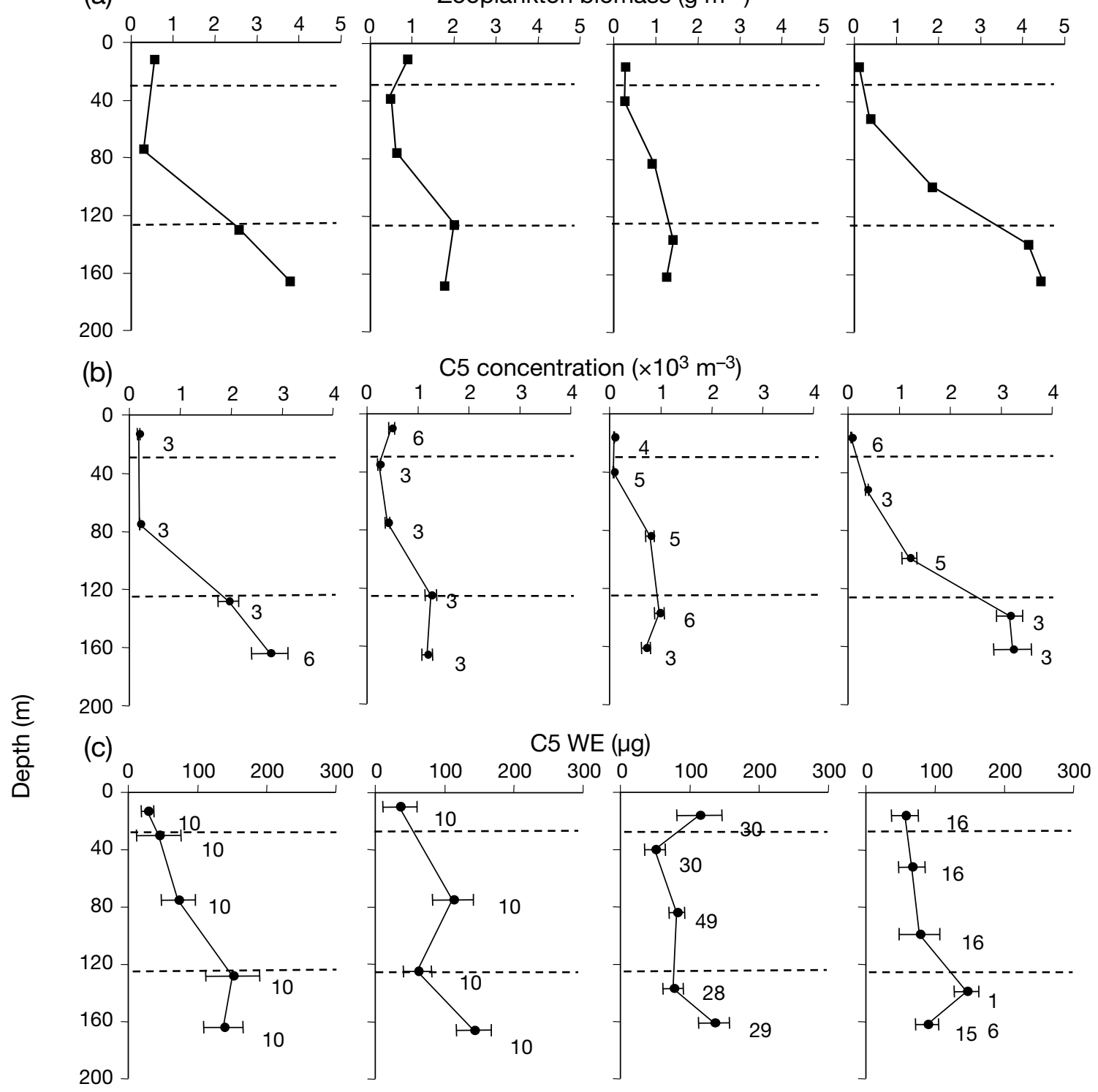

(d)

C5 WE energy density $\left(\mathrm{kJ} \mathrm{m}^{-3}\right)$
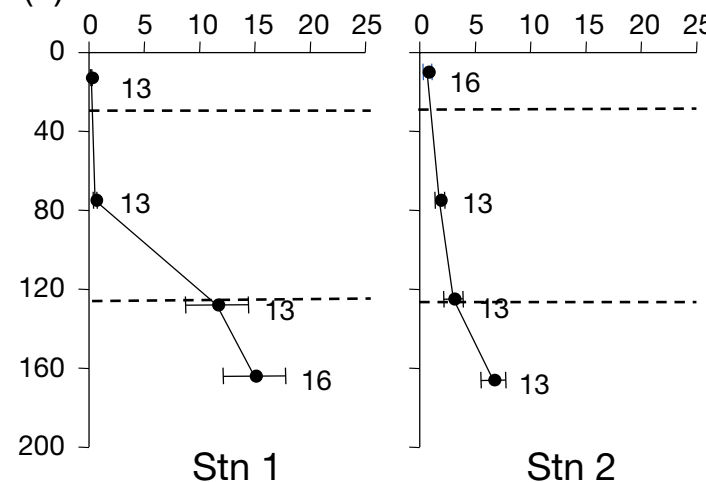

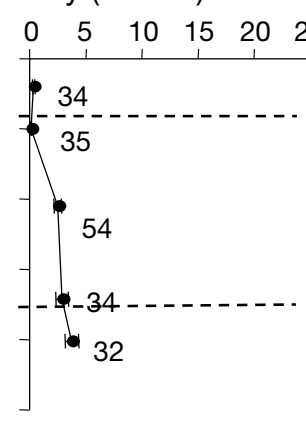

Stn 3

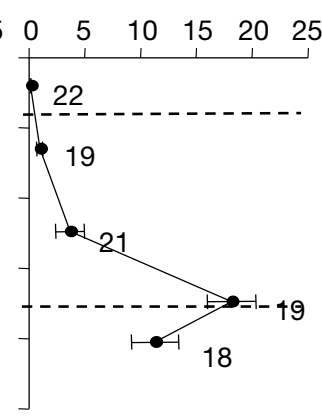

$\operatorname{Stn} 4$

Fig. 5. Semidiurnal tidal variation in the vertical distribution of (a) zooplankton total biomass ( $\mathrm{g} \mathrm{m}^{-3}$ ), (b) Copepodite Stage 5 (C5) concentration $\left(\mathrm{m}^{-3}\right)$, (c) individual C5 wax ester (WE) content ( $\left.\mu \mathrm{g}\right)$ and (d) C5 energy density ( $\mathrm{kJ} \mathrm{m}^{-3}$ ) derived from concentration and individual amount of WE $(\mu \mathrm{g})$ in water masses associated with each BIONESS station series collection. The dashed lines in each panel indicate the 30 and $125 \mathrm{~m}$ depth limits that nominally define the surface, intermediate and deep waters. Numerals adjacent to error bars (2 SE around the mean) denote sample size 


\section{Small-scale variation in the food energy density}

The pattern of whale food vertical distribution and variation obtained with the BIONESS zooplankton collections was also observed in the data recorded using the TUBSS-OPC. For example, the transit sections of Transect B (Fig. 1b, Table 2) that covered 1 tidal cycle (high to high) illustrated that the C5 energy density typically exceeded $10 \mathrm{~kJ} \mathrm{~m}^{-3}$ in the deep-water stratum (Fig. 6). Maximum estimates of $\sim 30 \mathrm{~kJ} \mathrm{~m}^{-3}$ were observed at depths $>140 \mathrm{~m}$ during Transit 1 (ebbing tide) and $45 \mathrm{~kJ} \mathrm{~m}^{-3}$ during Transit 3 (flooding tide). As these $\mathrm{C} 5$ high energy density patches are advected with the tide, as inferred for the station sampling series above, they probably represent the same water mass, and we can infer a patch extent of 4 to $8 \mathrm{~km}$ across the Basin and approximately orthogonal to the major axis of the tidal ellipse.

The Stn 5 sequential-net spatial sampling series, conducted coincidently with the BIONESS-OPC data collection at an average depth of $107 \pm 5 \mathrm{~m}$, shows that variation in C5 concentration, lipid content and energy density in the deep water was not negligible at horizontal scales of $\sim 500 \mathrm{~m}$ (Fig. 7). During the $0.5 \mathrm{~h}$ period used to complete this series, the tidal current averaged $0.51 \mathrm{~m} \mathrm{~s}^{-1}$ toward the $\mathrm{NE}$, and the tow speed of the net averaged $0.91 \mathrm{~m}$ $\mathrm{s}^{-1}$. Thus, the net collections that were oriented into the flooding tide allowed us to resolve a greater distance of $\sim 2 \mathrm{~km}$ in water mass space. Average C5 concentration among net collections varied by a factor of 3 , as did the individual WE content (Fig. 7c) and thus energy density (Fig. 7d) within this water mass.

Data from the BIONESS-OPC provided a higher resolution estimate of the spatial variation in C5 concentration at depth within 1 water mass as indicated by relatively constant
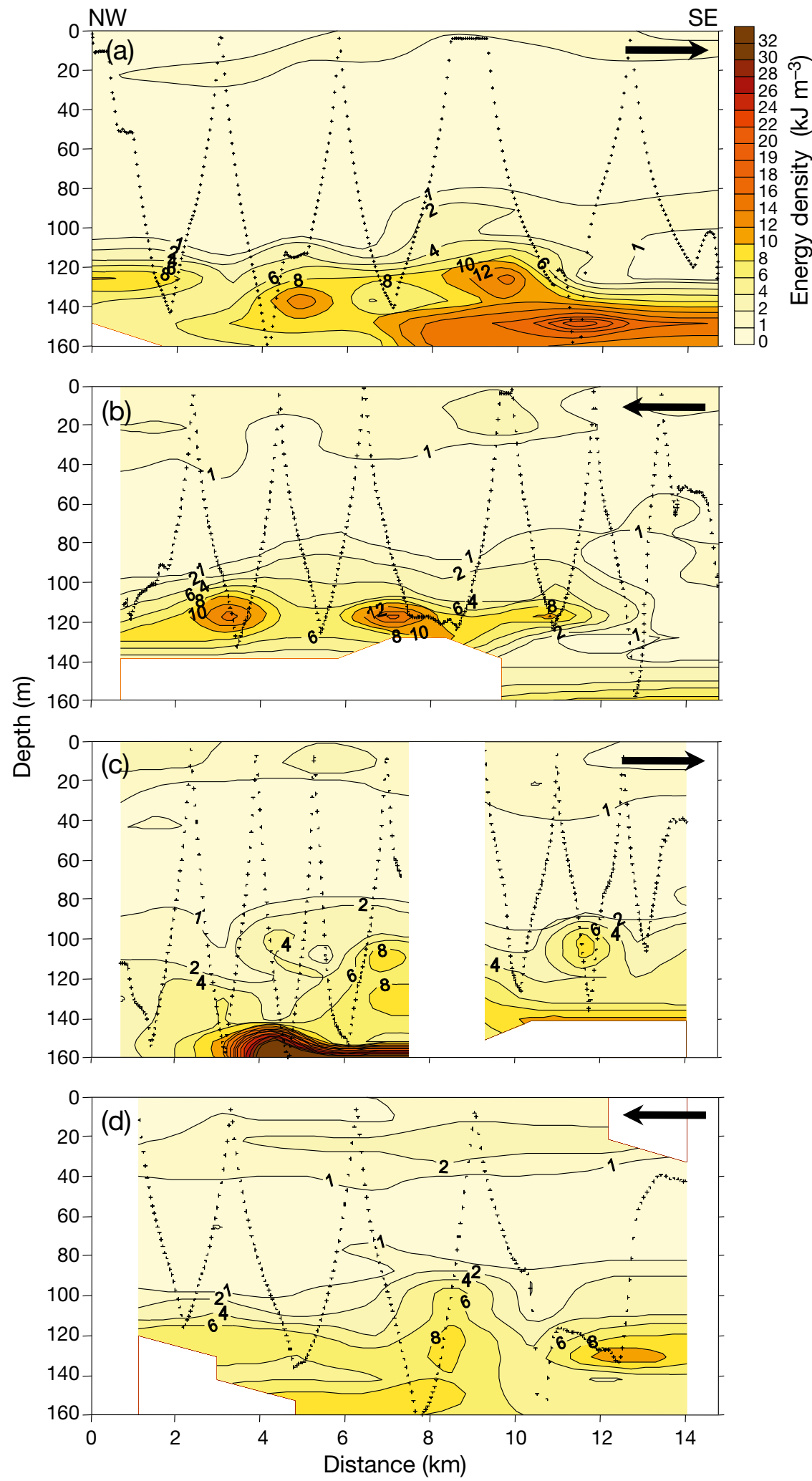

Fig. 6. Sectional distribution of Copepodite Stage 5 (C5) energy density (kJ $\mathrm{m}^{-3}$ ), estimated using the towed underwater biological sensor system-optical particle counter (TUBSS-OPC) in September 2002 in the Grand Manan Basin along the distance-scaled NW to SE Transect B of each of Transits 1 to 4 (a to d). Arrow in each panel indicates direction of tow 


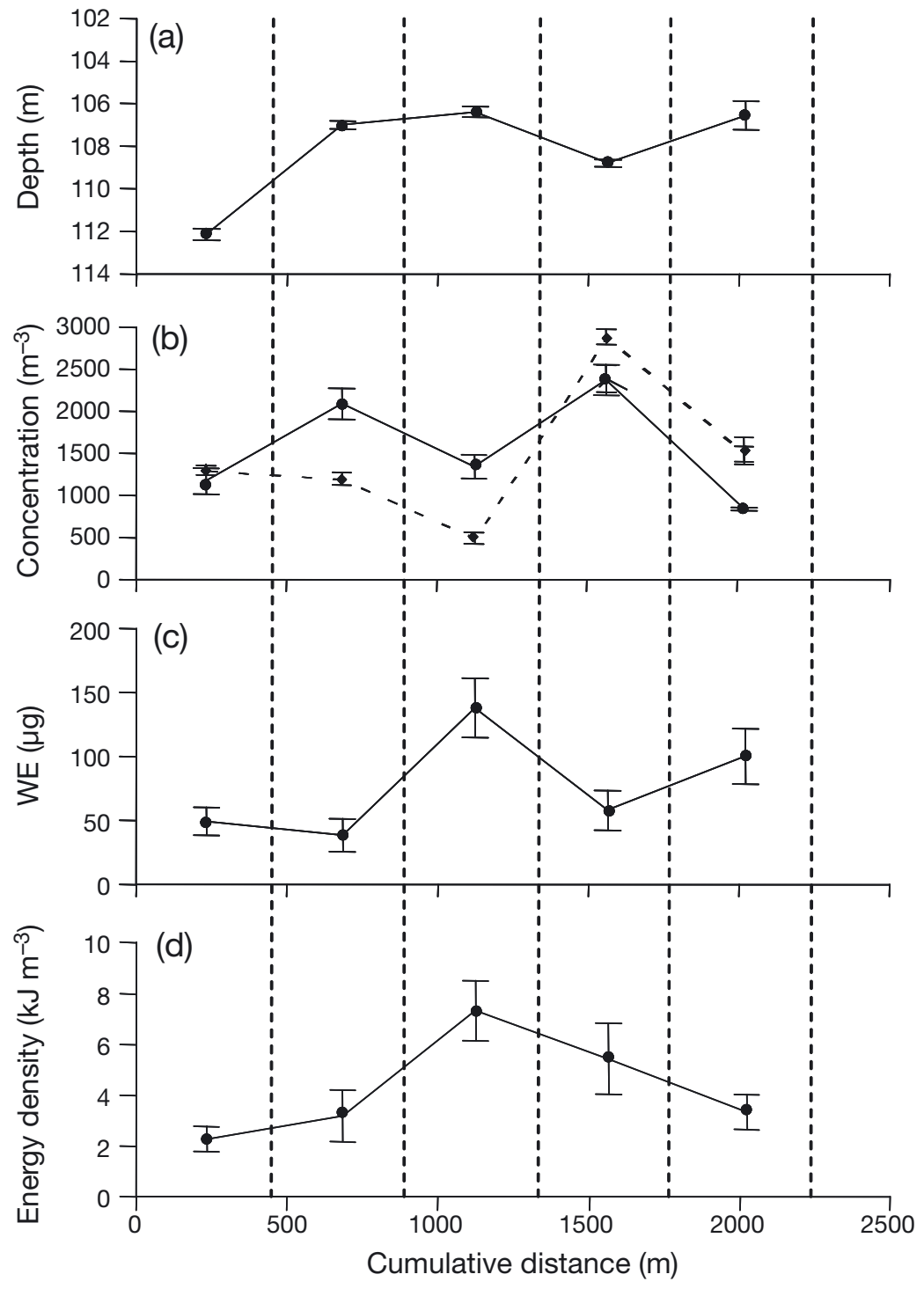

Fig. 7. Moderate horizontal resolution of spatial variation $\left(1.42 \mathrm{~m} \mathrm{~s}^{-1}\right)$ at depth at Stn 5 in the Grand Manan Basin showing (a) depth of BIONESS net deployment, (b) concentration estimates of Copepodite Stage 5 individuals (C5s) derived from the net collections $(\mathbf{0},-)$ and BIONESS-OPC C5 concentration as estimated by the calibration of the optical particle counter $(\bullet$ ---), (c) C5 wax ester (WE) content and (d) WE energy density estimated from net-collected C5 concentration and WE. The vertical dashed lines show the positions of sequential opening and closing of the nets. Error bars represent $\pm 2 \mathrm{SE}$ around the mean

temperature, salinity and density while sampling a relatively constant depth (Fig. 8). The concentration of C5s (and therefore energy density) varied by at least a factor of 8 over distances of 250 to $500 \mathrm{~m}$ and there was no clear evidence that the variation was related to water temperature, salinity or density. Interpretation of the OPC data is reliable because the grand means for $\mathrm{C} 5$ concentration among the net collection series (Fig. $7 b$ ) and the mean of the OPC series (Fig. 8) were similar at $1566 \mathrm{~m}^{-3}$ and $1473 \mathrm{~m}^{-3}$, respectively.

\section{Integrated food energy density at the scale of the Grand Manan Basin}

The relative probability of observing a right whale during June through October by using data aggregated over the period from 1987 through 2000 in the Grand Manan Basin region (derived from Vanderlaan et al. 2008) shows that the right whales are historically distributed in the Basin area and are most concentrated within the 140$180 \mathrm{~m}$ isobath in an elliptical manner oriented SW to NE (Fig 9a), i.e. the probability distribution of the whales is a scaled reflection of the tidal ellipse. The method of advecting all the OPC data from each of the TUBSS transits among all transects (Table 2) from their original geographic locations and times to their new locations at common times at either end of the tidal excursion (i.e. at high tide and at low tide) provided quasi-synoptic planar estimates of the food energy density over an area covering $\sim 280 \mathrm{~km}^{2}$ located toward the NE and the up-slope margin of the Basin (Fig. 9b-d) and to the SW and down-slope (Fig. 9e-g). At high tide and among the 3 different 20 $m$ thick strata, patches of high energy density ranging from 6 to $25 \mathrm{~kJ} \mathrm{~m}^{-3}$ were observed at different geographic locations and among the depth strata. Consistent with those observed in the BIONESS vertical distribution data (Fig. 5) and with the TUBSS sectional profiles (Fig. 6), the highest energy densities, $>10 \mathrm{~kJ} \mathrm{~m}^{-3}$, were located at depths of $>140 \mathrm{~m}$. The extent of these high energy patches in water mass space is typically in the 4 to $6 \mathrm{~km}$ range $\left(7\right.$ to $37 \mathrm{~km}^{2}$ ). Given the tidal advection, these patches would be distorted as they are translated $\sim 8 \mathrm{~km}$ to the SW during the ebbing tide, and thus, both the high and low tide planar views of the prey field indicate that highest energy densities coincide with highest historical right whale sightings in the Basin. 


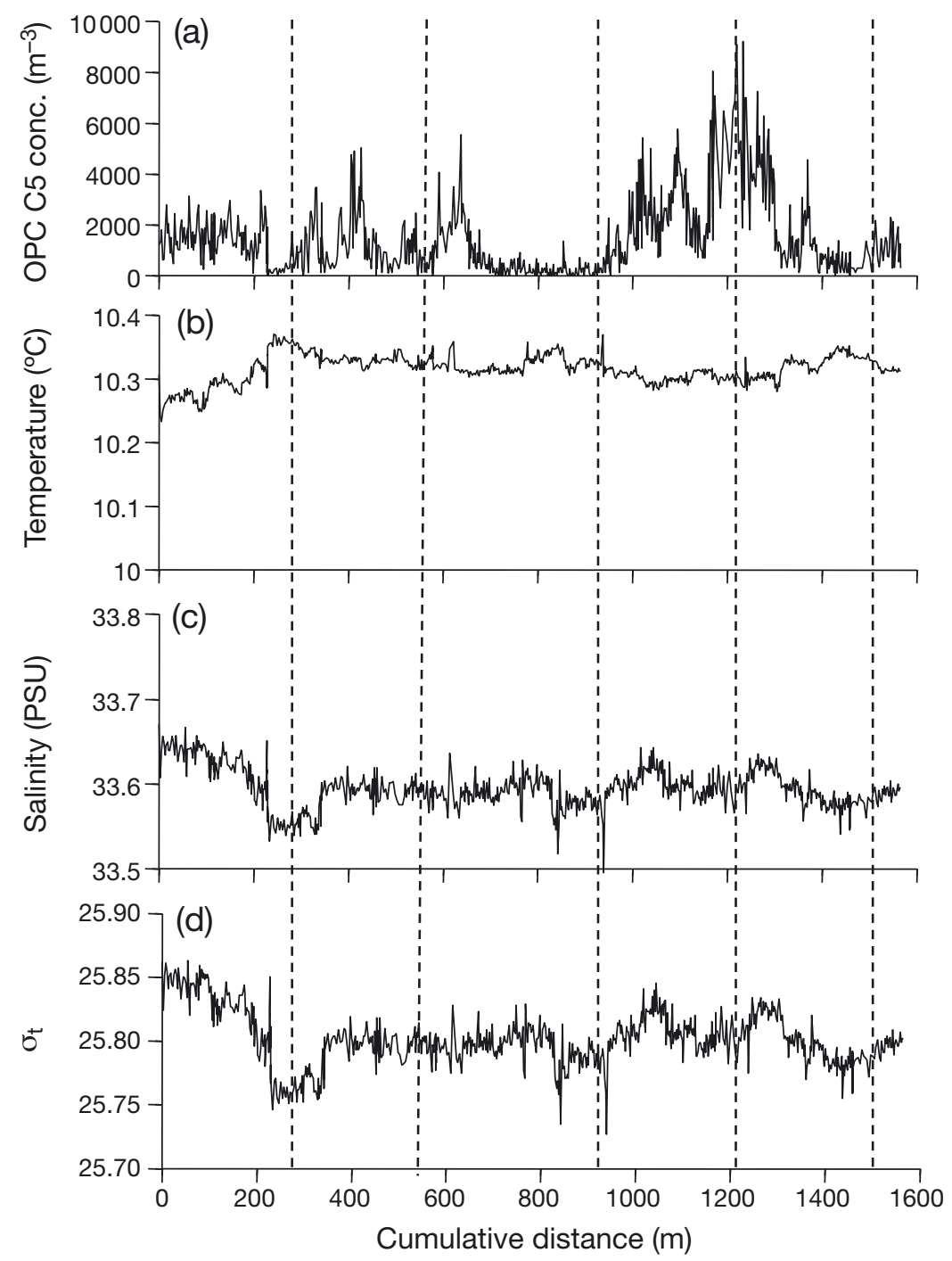

Fig. 8. High horizontal resolution $(\sim 3 \mathrm{~m})$ of spatial variation $\left(1.42 \mathrm{~m} \mathrm{~s}^{-1}\right)$ at depth at Stn 5 in the Grand Manan Basin showing (a) OPC-derived Copepodite Stage 5 (C5) concentration, (b) water temperature, (c) salinity and (d) density $\left(\sigma_{t}\right)$. Vertical dashed lines show the position of sequential opening and closing of the concomitantly deployed BIONESS nets used to collect the C5s illustrated in Fig. 7

\section{DISCUSSION}

\section{Zooplankton biomass, C5 concentration and energy content at tidal scales}

Variation in water temperature and salinity below $80 \mathrm{~m}$ in the Grand Manan Basin clearly indicates that the time-varying characteristics of the deeper water masses are most easily explained by the semidiurnal tide. It appears that the warmer, saltier and denser water in the deeper-water stratum of the Basin has some spatial limit near that of the tidal excursion and contains within it Calanus finmarchicus C5 energy density estimates approaching an order of magnitude higher than in the adjacent cooler, fresher and less dense water.

The deep-water strata sampled at Stns 1 and 4 originated from a region in the Basin that was $\sim 20 \mathrm{~m}$ deeper than the sampling locations, and this water was tidally advected up-slope across isobaths to locations where the samples were collected. The up-slope phase of the tide may create turbulent overturning (up-slope mixing) that changes the thickness and the stratification of layers near the bottom (e.g. van Haren 2005). It seems reasonable to speculate that the diapausing and neutrally dense C5s, mainly concentrated near the bottom in the higher density water, are mixed upward as the flood-tide waters flow up-slope and then sink back during the following ebb tide into the higher density water from whence they came. Such a mixing process could favour the maintenance of the diapausing copepod aggregation and thus explain the higher C5 concentrations observed at Stns 1 and 4 near high tide as well as the change in the TS signature between 120 and $160 \mathrm{~m}$ as observed at Stn 1.

From the results above, we can tentatively conclude that Basin topography, the orientation of the tidal ellipse, tidal residual currents, water-mass properties (e.g. density), diapausing copepod abundance at depth, their enhanced lipid-energy content and the passive behaviour associated with diapausing form the essential combination that provides sufficient food energy to make the Grand Manan Basin a primary right whale foraging habitat. The recent modelling studies of Aretxabaleta et al. (2008) are consistent with this interpretation and are further detailed below. The findings of Baumgartner \& Mate (2003) and Baumgartner et al. (2003b) report a positive relation between the depth of a deep mixed layer and C5 concentration and suggest that copepods accumulate just above that deep mixed layer. Our data reveal no such correlation between the depth of the deep mixed layer (determined with the same Baumgartner \& Mate 2003 criterion) and C5 


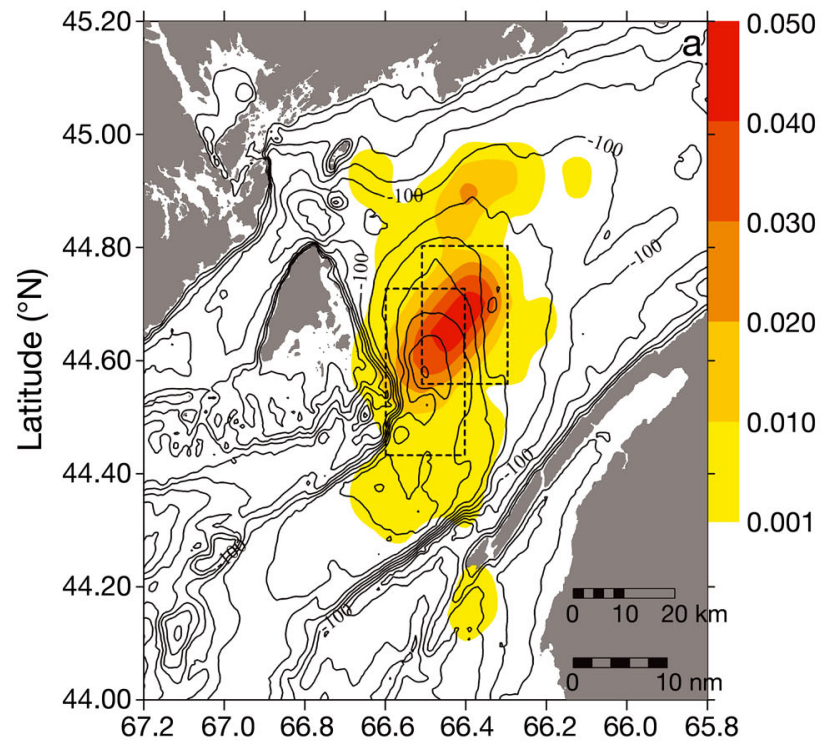

Fig. 9. Bathymetric chart (20 m isobath interval) of the Grand Manan Basin showing (a) the relative probability (colour contour) of observing a right whale during June through October (from Vanderlaan et al. 2008) with insets (dashed rectangles) that are separated by the $\sim 8 \mathrm{~km}$ tidal excursion corresponding to the planar distribution of average integrated C5 energy density ( $\mathrm{kJ} \mathrm{m}^{-3}$ ) over the 100 to 120,120 to 140 , and 140 to $160 \mathrm{~m}$ depth strata advected $(\mathrm{b}, \mathrm{c}, \mathrm{d})$ up-slope to a common high tide state and $(e, f, g)$ down-slope to a common low tide state. Solid symbols indicate each datum used in contouring the estimates
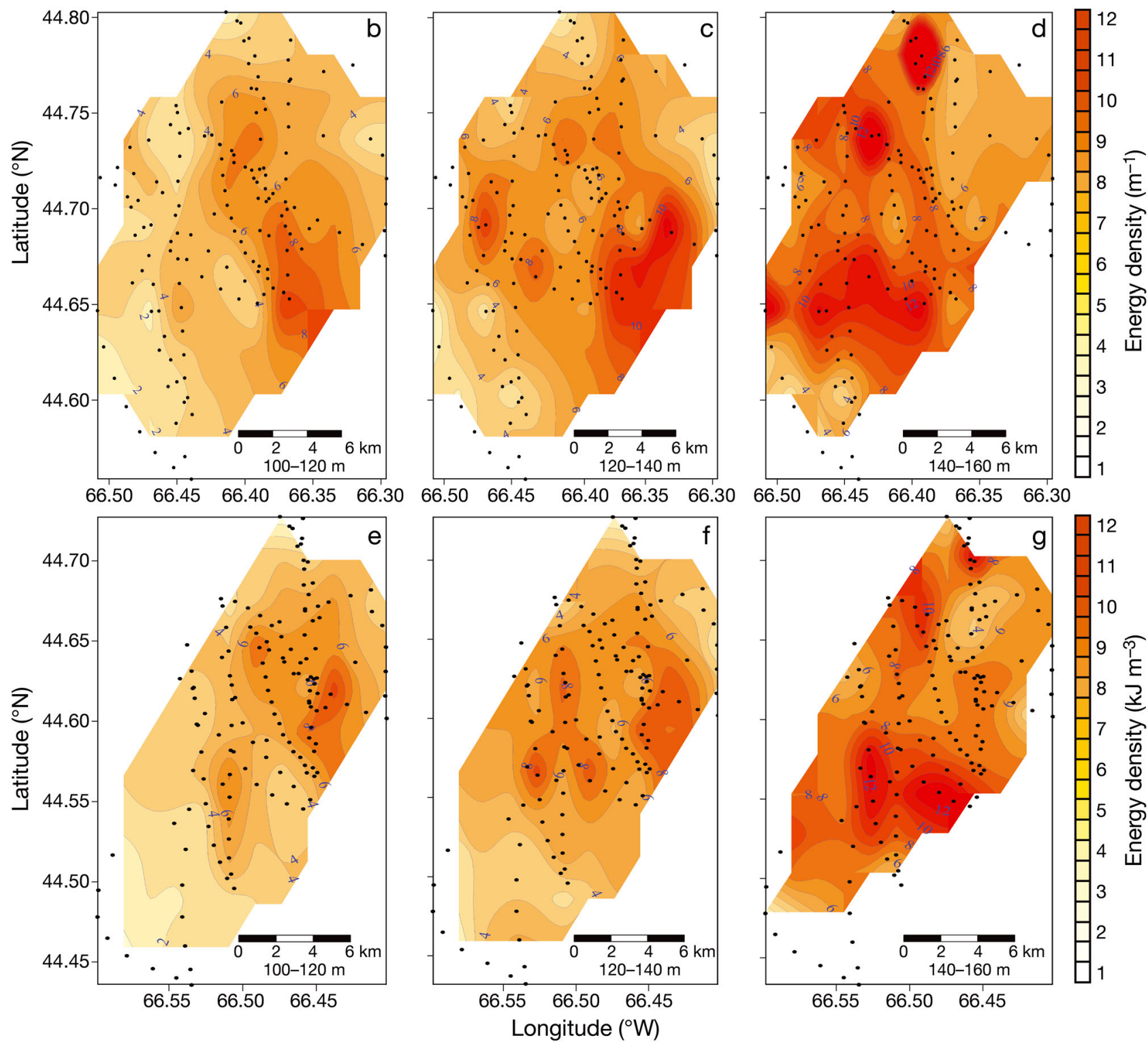
concentration, though our limited number of station collections (i.e. 4) suitable to test the relation is small. However, the up-slope advection and mixing process associated with the flooding tide that we describe above could explain the reported correlation between C5 concentration and the depth of the deep mixed layer.

\section{Small-scale variation in the prey field energy density}

The lipid-energy density of C5s in the water column showed variations directly linked to the tide and sufficient to affect the foraging success and net energy return for foraging right whales. Right whale basal energy demand, i.e. the food energy density necessary for a resting, post-absorptive and thermoneutral adult weighing $40000 \mathrm{~kg}$ was estimated at $\sim 8.79 \mathrm{~kJ} \mathrm{~m}^{-3}$ by Kenney et al. (1986). In our study, the food energy density levels sufficient to meet this basal energy demand occurred only as patches in water masses at depths between 140 and $180 \mathrm{~m}$, and the patches were advected by the tide within the Basin. Baumgartner et al. (2003a) also observed patchiness in the distribution of $\mathrm{C} 5 \mathrm{~s}$, consistent with the tidal advection patterns we observed, and they suggest that these C5s patches are persistent in time. We further suggest that the level of integrity of these deep patches is at least associated with the semidiurnal scale, and probably at the longer $7 \mathrm{~d}$ scale resolved by our sampling programme. The persistence of the deep patches thus presents a 'predictable' source of energy-dense food to the advantage of the right whales.

Baumgartner et al. (2003a) also reported that the correlation between right whale sightings and C5 concentration and the tidal state results from the advection of the whales and their food. This argument was based on the observation that the variability in right whale sightings and the fixed location estimates of C5 concentration between 90 and $140 \mathrm{~m}$ had the same periodicity as the tide. Results from our BIONESS station series and TUBSS transect series are entirely consistent with this interpretation, though at a somewhat greater depth. Further, Laurinolli (2002) resolved a clear relation between tidal displacement and the displacement of right whales in the Grand Manan Basin, i.e. at short time scales the whales are advected with the tide. From an efficiency perspective, it appears that the right whales are foraging while being tidally advected and are within the residual tidal eddy along with their food resource, especially if the energy density of the food being advected with them is sufficient to meet basic metabolic demands. Therefore, the tidally driven variation in the abundance distribution of $\mathrm{C} 5 \mathrm{~s}$, as illustrated in the present study, represents the simplest explanation for the distribution of right whales in the Grand Manan Basin region on at least a semidiurnal scale and apparently at a scale of weeks to months (see next section).

\section{Integrated food energy density and right whale distribution at the scale of the Grand Manan Basin}

Variations in the food energy density observed at 1 location appear to be also observed at the scale of the Basin. Our depth-integrated planar view of the prey field revealed that patches of maximum food energy densities of $25 \mathrm{~kJ} \mathrm{~m}^{-3}$ occur in the 140 to $160 \mathrm{~m}$ stratum and coincide with the probabilistic right whale distribution. However, energy density estimates integrated across each depth stratum were relatively low considering the right whale basal metabolic demand, but as they were integrated over a $20 \mathrm{~m}$ stratum they are subject to 'numerical dilution'. When integrating across strata using only energy densities at depths that are $>10 \mathrm{~kJ} \mathrm{~m}^{-3}$, we obtain a different view of the prey field (Fig. 10) with energy density estimates $>15 \mathrm{~kJ} \mathrm{~m}^{-3}$ and thus 1.5 to 4 -fold greater than the basal metabolic demand of the whales. The estimates we present in Figs. $9 \& 10$, now distributed in water mass space, provide a first approximation of the basin-wide energy available to the whales within the right whale's critical habitat (Brown et al. 2009). Considering that tidal currents are the dominating factor that control the advective distribution of $\mathrm{C} 5 \mathrm{~s}$, it should come as no surprise that the historical abundance distribution of the whales in the Grand Manan Basin is elliptical, with the major axis paralleling that of the tidal ellipse, giving credence to the several published suggestions that the whales are advected along with their food while foraging in the Basin (e.g. Baumgartner et al. (2003a).

The interaction of the life history strategies of an organism, such as ontogenetic migration, with prevailing currents can result in the aggregation and spatial persistence (though not necessarily retention) of organisms in defined areas (Mackas et al. 1997, Simard \& Lavoie 1999, Cotté \& Simard 2005). For example, in the eastern North Atlantic Ocean, a particle-tracking model demonstrated that ontogenetic vertical migration coupled with seasonal currents explained the geographic persistence of Calanus finmarchicus and thus their transport to and from basins 


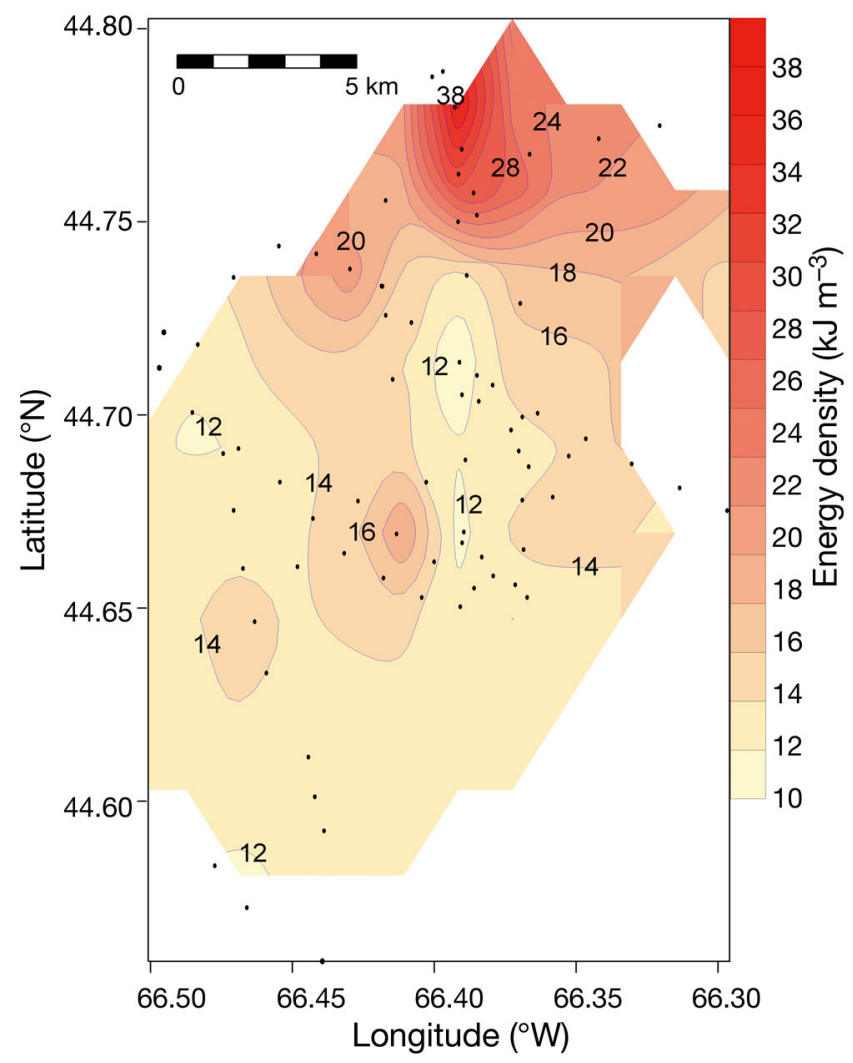

Fig. 10. Planar distribution of the average integrated C5 energy density $\left(\mathrm{kJ} \mathrm{m}^{-3}\right)$ in the Grand Manan Basin based on the integration over the 100 to $160 \mathrm{~m}$ depth stratum where energy density was $\geq 10 \mathrm{~kJ} \mathrm{~m}^{-3}$ and advected up-slope to a common high-tide state (see high tide insets in Fig. 9a). Solid symbols indicate each datum used in contouring the $\geq 10 \mathrm{~kJ} \mathrm{~m}^{-3}$ estimates

during certain seasons (Bryant et al. 1998). Our results show very little evidence of ontogenetic migration patterns in the C5s to suggest that a coupling of behaviour with vertically structured currents is influencing the observed aggregation and persistence of the diapausing C5s. Tidal forcing may be responsible for the persistence of C5s in the Grand Manan Basin, though our data are insufficient to address long-term retention and/or advective (current-driven) immigration and emigration. Michaud \& Taggart (2007) argued that seasonal variation in abundances and calculated development times of C5s suggests transport of generations of $C$. finmarchicus in the Basin from other areas, possibly the Scotian Shelf (e.g. Herman et al. 1991). The presence of the higher C5 concentrations in the saltier and denser waters, hence probably of oceanic origin, tends to agree with this postulate, although it remains to be verified.

Suggestions of a persistent cyclonic gyre centred over the high-probability distribution of right whales in the Grand Manan Basin (Fig. 9a) originated with Watson (1936), and recent baroclinic numerical modelling by Aretxabaleta et al. (2008) demonstrates tidally driven oceanographic processes that are fully consistent with many of our interpretations. The most salient features of the cited numerical modelling results, and of direct relevance to our findings, derive from the fact that the gyre is generated by tidal rectification and density-driven (buoyancy-forcing) circulation that results in (1) gyre circulation being stronger during periods of stratification (July through October), the time when the whales and their prey are at highest concentrations, (2) the density-driven flow around the gyre being generated by weak tidal mixing in the deep Basin coupled with strong tidal mixing on the shallow margins, which reflects both the location and margins encompassing the elevated concentrations of whales and C5s, and (3) passiveparticle retention within the Basin for periods of $>30 \mathrm{~d}$ that results from the residual tidal circulation and frontal retention that is enhanced during stratification; this explains the maintenance of high C5 concentrations. Aretxabaleta et al. (2008) show that passive-particle retention increases with depth where it results in accumulation, a process that would maintain and increase the C5 food energy density at depth. The same authors also illustrate a generally closed recirculating velocity field in the 120 to $140 \mathrm{~m}$ depth range that is centred over the deepest part of the Basin during the period from July through October, which is consistent with the location and depth strata where we observed some of the highest concentrations of C5s.

Our results revealed a slight increase in C5 concentration at night in the surface mixed layer that may be attributable to diel vertical migration and/or differences in the water mass properties owing to the semi diurnal tide. However, this nighttime increase in surface C5 concentration does not compromise our findings as it was small and at most amounted to $1 \mathrm{~kJ} \mathrm{~m}^{-3}$, and is thus well below right whale basal energy requirements. It appears that whale foraging effort is ecologically efficient if concentrated in the deep layer at any time of day or night. Baumgartner \& Mate (2003) reported that right whales concentrate their foraging efforts during the day, though they did not exclude possible surface feeding at night

The C5s in the Grand Manan Basin are diapausing at depths shallower than those typically reported for other regions of the Atlantic Ocean (e.g. Hirche 1996, Heath 1999, Halvorsen et al. 2003). This provides an advantage for foraging right whales, i.e. the reduced 
energetic cost of diving to shallow depths and thus a longer foraging time. Right whale feeding at increased depth involves an increased dive time and a reduced ingestion rate at depth. For example, the ingestion rate can be reduced by 8 to $19 \%$ when foraging at $140 \mathrm{~m}$ compared with foraging at $50 \mathrm{~m}$ (Baumgartner et al. 2003a). Thus, it would be too costly for a right whale to feed below a certain depth, even if high-energy food concentrations were available. This may explain why the high concentrations of right whales in the Grand Manan Basin area are not observed in the other and deeper basins of the Scotian Shelf where C5s also accumulate, though at depths well below 200 m (Sameoto \& Herman 1990, Herman et al. 1991). The only exception is Roseway Basin on the Scotian Shelf where right whales also aggregate in summer and autumn, and there the maximum depth is ca. $150 \mathrm{~m}$, which is directly comparable to the Grand Manan Basin.

In summary, the spatial and temporal variation in the prey field for right whales that we document here for the Grand Manan Basin appears to define the domain where foraging right whales would be most able to meet their energy demands. To forage efficiently, and at least to meet their basal energy demand - and perhaps other costs associated with migration, reproduction, lactation and fat storage, for example-it appears that right whales would be most successful if they feed actively on the energyrich concentrations of food as they and their food are advected with the tide while being maintained within the tidally forced gyre. Whether there is enough energy in the Grand Manan Basin to meet all of the energy requirements for a right whale population, and what the carrying capacity of the Basin region might be, remain questions we hope to answer in the future.

Acknowledgements. We thank the officers and crew of CFAV 'Quest' and F. Desharnais for their support, and W. Judge, K. Collins, D. Schillinger, T. Cheney, A. Serdynska and A. Vanderlaan for their assistance in the field and laboratory. Funding from FCAR to J.M. and from NSERC Shiptime and Discovery, DFO Science and Youth Internship Program, and the Species at Risk Program to C.T.T. supported the research.

\section{LITERATURE CITED}

Aretxabaleta AL, McGillicuddy DJ Jr, Smith KW, Lynch DR (2008) Model simulations of the Bay of Fundy Gyre: 1. Climatological results. J Geophys Res 113:C10027, doi: 10.1029/2007JC004480

Baumgartner MF, Mate BR (2003) Summertime foraging ecology of North Atlantic right whales. Mar Ecol Prog Ser 264:123-135
Baumgartner MF, Cole TVN, Campbell RG, Teegarden GJ, Durbin EG (2003a) Associations between North Atlantic right whales and their prey, Calanus finmarchicus, over diel and tidal time scales. Mar Ecol Prog Ser 264:155-166

Baumgartner MF, Cole TVN, Clapham PJ, Mate BR (2003b) North Atlantic right whale habitat in the lower Bay of Fundy and on the SW Scotian Shelf during 1999-2001. Mar Ecol Prog Ser 264:137-154

Bevington PR, Robinson K (2003) Data reduction and error analysis for the physical sciences, 3rd edn. McGraw-Hill, Boston, MA

Brown MW, Brault S, Hamilton PK, Kenney RD and others (2001) Sighting heterogeneity of right whales in the western north Atlantic: 1980-1992. J Cetacean Res Manag 2(Spec Issue):245-250

Brown MW, Fenton D, Smedbol RK, Merriman C, Robichaud-Leblanc K, Conway JD (2009) Recovery strategy for the North Atlantic right whale (Eubalaena glacialis) in Atlantic Canadian waters. Species at Risk Act Recovery Series, Fisheries and Oceans Canada, Ottawa

> Bryant AD, Hainbucher D, Heath M (1998) Basin-scale advection and population persistence of Calanus finmarchicus. Fish Oceanogr 7:235-244

Caswell H, Fujiwara M, Brault S (1999) Declining survival probability threatens the North Atlantic right whale. Proc Natl Acad Sci USA 96:3308-3313

Clapham PJ, Cole T (1999) Surveys for right whales and other mysticetes on the Scotian Shelf, summer 1999. Right Whale Consortium Meeting, Boston, MA, 21-22 Oct 1999 (Abstract)

Cotté C, Simard Y (2005) Formation of dense krill patches under tidal forcing at whale feeding hot spots in the St. Lawrence Estuary. Mar Ecol Prog Ser 288:199-210

DeLorenzo Costa A, Durbin EG, Mayo CA, Lyman EG (2006) Environmental factors affecting zooplankton in Cape Cod Bay: implications for right whale dynamics. Mar Ecol Prog Ser 323:281-298

Fujiwara M, Caswell H (2001) Demography of the endangered North Atlantic right whale. Nature 414:537-541

> Greenberg DA (1983) Modeling the mean barotropic circulation in the Bay of Fundy and Gulf of Maine. J Phys Oceanogr 13:886-904

> Halvorsen E, Tande KS, Edvardsen A, Slagstad D, Pedersen OP (2003) Habitat selection of overwintering Calanus finmarchicus in the NE Norwegian Sea and shelf waters off Northern Norway in 2000-02. Fish Oceanogr 12: 339-351

> Hannah CG, Shore J, Loder W, Naimie CE (2001) Seasonal circulation on the western and central Scotian Shelf. J Phys Oceanogr 31:591-615

Heath MR (1999) The ascent migration of Calanus finmarchicus from overwintering depths in the Faroe-Shetland Channel. Fish Oceanogr 8(Suppl 1):84-99

> Herman AW (1988) Simultaneous measurement of zooplankton and light attenuance with a new optical plankton counter. Cont Shelf Res 8:205-221

Herman AW (1992) Design and calibration of a new optical plankton counter capable of sizing small zooplankton. Deep-Sea Res 39:395-415

> Herman AW, Sameoto DD, Chen S, Mitchell MR, Petrie B, Cochrane N (1991) Sources of zooplankton on the Nova Scotia shelf and their aggregations within deep-shelf basins. Cont Shelf Res 11:211-238 
Hirche HJ (1996) Diapause in the marine copepod, Calanus finmarchicus - a review. Ophelia 44:129-143

Kattner G, Hagen W (1995) Polar herbivorous copepods different pathways in lipid biosynthesis. ICES J Mar Sci 52:329-335

Kenney RD, Hyman MAM, Owen RE, Scott GP, Winn HE (1986) Estimation of prey densities required by western North Atlantic right whales. Mar Mamm Sci 2:1-13

Kenney RD, Winn HE, Macaulay MC (1995) Cetaceans in the Great South Channel, 1979-1989: right whale (Eubalaena glacialis). Cont Shelf Res 15:385-414

Kenney RD, Mayo CA, Winn HE (2001) Migration and foraging strategies at varying spatial scales in western North Atlantic right whales: a review of hypotheses. J Cetacean Res Manag 2(Spec Issue):251-260

Knowlton AR, Kraus SD, Kenney RD (1994) Reproduction in North Atlantic right whales (Eubalaena glacialis). Can J Zool 72:1297-1305

Kraus SD, Hamilton PK, Kenney RD, Knowlton AR, Slay CK (2001) Reproductive parameters of the North Atlantic right whale. J Cetacean Res Manag 2(Spec Issue): 231-236

Kraus SD, Brown MW, Caswell H, Clark CW, and others (2005) North Atlantic right whales in crisis. Science 309: 561-562

Lamprecht I (1999) Combustion calorimetry. In: Kemp RB (ed) Handbook of thermal analysis and calorimetry, Vol 4: from macromolecules to man. Elsevier Science, Amsterdam, p 175-187

Laurinolli MH (2002) Localisation of North Atlantic right whale (Eubalaena glacialis) sounds using hydrophone arrays in the Bay of Fundy. MSc thesis, Dalhousie University, Halifax

Lockyer C (1984) Review of baleen whale (Mysticeti) reproduction and implications for management. Rep Int Whal Comm Spec Issue 6:27-50

Lynch DR, Werner FE, Greenberg DA, Loder JW (1992) Diagnostic model for baroclinic, wind-driven and tidal circulation in shallow seas. Cont Shelf Res 12:37-64

Mackas DL, Kieser R, Saunders M, Yelland DR, Brown RM, Moore DF (1997) Aggregation of euphausiids and Pacific hake (Merluccius productus) along the outer continental shelf off Vancouver Island. Can J Fish Aquat Sci 54: 2080-2096

McLaren IA, Corkett CJ (1984) Life cycles and production of two copepods on the Scotian Shelf, eastern Canada. Syllogeus (Nat Mus Can) 58:362-368

McLaren IA, Head E, Sameoto DD (2001) Life cycles and seasonal distributions of Calanus finmarchicus on the central Scotian Shelf. Can J Fish Aquat Sci 58:659-670

Michaud J (2005) The prey field of the North Atlantic right whale in the Bay of Fundy: spatial and temporal variation. $\mathrm{PhD}$ thesis, Dalhousie University, Halifax

Michaud J, Taggart CT (2007) Lipid and gross energy content of North Atlantic right whale food, Calanus finmarchicus, in the Bay of Fundy. Endang Species Res 3: 77-94

Editorial responsibility: Clive McMahon,

Darwin, Northern Territory, Australia
Moore MJ, McLellan WA, Daoust PY, Bonde RK, Knowlton AR (2007) Right whale mortality: a message from the dead to the living. In: Kraus SD, Rolland RM (eds) The urban whale: North Atlantic right whales at the crossroads. Harvard University Press, Cambridge, MA, p 358-379

Murison LD, Gaskin DE (1989) The distribution of right whales and zooplankton in the Bay of Fundy, Canada. Can J Zool 67:1411-1420

> Patrician MR, Kenney RD (2010) Using the continuous plankton recorder to investigate the absence of North Atlantic right whales (Eubalaena glacialis) from the Roseway Basin foraging ground. J Plankton Res 32: 1685-1695

Payne PM, Wiley DN, Young SB, Pittman S, Clapham PJ, Jossi JW (1990) Recent fluctuations in the abundance of baleen whales in the southern Gulf of Maine in relation to changes in selected prey. Fish Bull 88: $687-696$

Reeves RR (2001) Overview of catch history, historic abundance and distribution of right whales in the western North Atlantic and in Cintra Bay, West Africa. J Cetacean Res Manag 2(Spec Issue):187-192

Sameoto DD, Herman AW (1990) Life cycle and distribution of Calanus finmarchicus in deep basins on the Nova Scotia shelf and seasonal changes in Calanus spp. Mar Ecol Prog Ser 66:225-237

Sameoto DD, Jaroszynski LO, Fraser WB (1980) BIONESS, a new design in multiple net zooplankton samplers. Can J Fish Aquat Sci 37:722-724

Schaeff CM, Kraus SD, Brown MW, White BN (1993) Assessment of the population structure of western North Atlantic right whales (Eubalaena glacialis) based on sighting and mtDNA data. Can J Zool 71:339-345

Simard Y, Lavoie D (1999) The rich krill aggregation of the Saguenay-St. Lawrence Marine Park: hydroacoustic and geostatistical biomass estimates, structure, variability, and significance for whales. Can J Fish Aquat Sci 56: 1182-1197

Sprules WG, Jin EH, Herman AW, Stockwell JD (1998) Calibration of an optical plankton counter for use in fresh water. Limnol Oceanogr 43:726-733

Taggart C, Thompson K, Maillet G, Lochmann S, Griffin D (1996) Abundance distribution of larval cod (Gadus morhua) and zooplankton in a gyre-like water mass on the Scotian Shelf. A. A. Balkema Publishers, Brookfield, VT

van Haren H (2005) Details of stratification in a sloping bottom boundary layer of Great Meteor Seamount. Geophys Res Lett 32:L07606, doi:10.1029/2004GL022298

- Vanderlaan ASM, Taggart CT, Serdynska AR, Kenney RD, Brown MW (2008) Reducing the risk of lethal encounters: vessels and right whales in the Bay of Fundy and on the Scotian Shelf. Endang Species Res 4:283-297

- Watson EE (1936) Mixing and residual currents in the tidal waters as illustrated in the Bay of Fundy. J Biol Board Can 2:141-208

Submitted: June 11, 2008; Accepted: July 29, 2011 Proofs received from author(s): November 10, 2011 